\title{
Drought response of upland oak (Quercus L.) species in Appalachian hardwood forests of the southeastern USA
}

\author{
Tara L. Keyser ${ }^{1} \cdot$ Peter M. Brown ${ }^{2}$
}

Received: 4 February 2016 / Accepted: 16 July 2016 / Published online: 12 September 2016

(C) INRA and Springer-Verlag France (outside the USA) 2016

\begin{abstract}
- Key message In Appalachian hardwood forests, density, stem size, and productivity affected growth during drought for red oak, but not white oak species. Minor effects of density suggest that a single low thinning does little to promote drought resilience for oaks in the region. - Context Management is increasingly focused on promoting resilience to disturbance. Because stand density can modulate climate-growth relationships, thinning may be an adaptation strategy that promotes resistance/resilience to drought.

- Aims We examined how density, manipulated via thinning, stem size, and site productivity, influences the drought response of northern red, black, chestnut, and white oak.

- Methods We modeled the role of density, stem size, and site productivity on resistance, recovery, and resilience during two drought events.

- Results Chestnut and white oak displayed greater resistance, recovery, and/or resilience than did northern red and black oak. For black oak, density and stem size negatively affected resistance during the first and second drought, respectively.
\end{abstract}

Handling Editor: Andreas Bolte

Contribution of the coauthors

Tara L. Keyser: data analysis and co-writing of the paper.

Peter M. Brown: chronology development and co-writing of the paper.

Tara L. Keyser

tkeyser@fs.fed.us

Peter M. Brown

pmb@rmtrr.org

1 USDA Forest Service, Southern Research Station, Bent Creek Experimental Forest, 1577 Brevard Rd, Asheville, NC 28806, USA

2 Rocky Mountain Tree Ring Research, Inc., 2901 Moore Ln, Fort Collins, CO 80526, USA
Density, stem size, and site productivity had no effect on chestnut and white oak.

- Conclusion The lack of sensitivity of chestnut and white oak to the ranges of density, stem size, and site productivity observed in this study and generally better resistance, recovery, and resilience suggests that management focused on the maintenance of these species, as opposed to a single silvicultural low thinning, may be a possible strategy for sustaining the growth and productivity of oak species in Appalachian hardwood stands. Drought response as affected by alternative thinning interventions should be evaluated.

Keywords Resistance $\cdot$ Resilience $\cdot$ Recovery $\cdot$ Climate change $\cdot$ Quercus $\cdot$ Appalachian Mountains

\section{Introduction}

Across the Appalachian-Cumberland region of the southeastern USA, forecasted changes in climate, which include an increase in temperature along with more variable precipitation patterns, are expected to result in an increase in the severity and frequency of extreme weather events, such as drought (McNulty et al. 2013). Drought is a primary disturbance agent affecting forest productivity at local, regional, and global scales (Boisvenue and Running 2006; Zhao and Running 2010; Chen et al. 2012). Drought-related decreases in forest productivity are associated with increased tree mortality (Elliott and Swank 1994; Jenkins and Pallardy 1995; Adams et al. 2009; Allen et al. 2010; Anderegg et al. 2012), reduced growth (Fekedulegn et al. 2003; Klos et al. 2009; D'Amato et al. 2013), and magnification of complex forest-insectdisease interactions which can, in turn, further exacerbate ongoing mortality and growth reductions (Clinton et al. 1993; Desprez-Loustau et al. 2006; Haavik et al. 2015). Drought- 
related declines in forest growth and productivity - whether caused by reductions in growth or increases in mortalityhave the potential to affect the sustained production of a variety of ecosystem services, including timber production (Hanewinkel et al. 2013), wildlife habitat and food resources (Sork et al. 1993), and terrestrial carbon storage (Zhao and Running 2010; Vayreda et al. 2012).

The vulnerability of tree species to drought-related reductions in growth is species- (e.g., Fekedulegn et al. 2003; Pan et al. 1997) or functional group-specific (Anderegg et al. 2015). In a recent study, Elliott et al. (2015) analyzed the variability of drought response of six prominent Appalachian hardwood species and observed the individual tree drought-growth relationships varied according to xylem architecture, with diffuse porous species (e.g., yellow-poplar (Liriodendron tulipifera L.), red maple (Acer rubrum L.), sweet birch (Betula lenta L.)) more susceptible to reduced growth than ring-porous oak (Quercus L.) species. Similarly, utilizing US Forest Inventory and Analysis data, Brzostek et al. (2014) reported that mesophytic species such as the yellow-poplar and sugar maple (Acer saccharum Marsh.), both diffuse porous species, exhibited greater reductions in growth during periods of chronic moisture stress than did xeric species such as chestnut oak (Quercus montana wild.) and white oak (Quercus alba L.). Beyond interspecific differences in response to drought, drought-growth relationships further vary across age (Copenheaver et al. 2011; MartínezVilalta et al. 2012), tree size (Zang et al. 2012; Keyser and Brown 2014), and compositional (Lebourgeois et al. 2013) and environmental (Orwig and Abrams 1997; Tardiff et al., 2003; White et al. 2011) gradients.

Forest management efforts are increasingly focused on promoting resistance and/or resilience to the potential effects of climate change, including drought at the tree, stand, and landscape level. Retrospective analyses suggest that individual tree- and stand-level growth during drought events is modulated by stand density and intraspecific and interspecific competitive interactions (Piutti and Cescatti 1997; D'Amato et al. 2013; Lebourgeois et al. 2013; Sánchez-Salguero et al. 2015). As such, the manipulation of stand density and associated competitive interactions via silvicultural thinning is advocated by many as an adaptation strategy that promotes the resilience of individual trees, stands, and forests to future droughtrelated decreases in growth and productivity (Bréda and Badeau 2008; Klos et al. 2009; Martin-Benito et al. 2010; Gómez-Aparicio et al. 2011).

Knowledge regarding tree- and stand-level resilience to drought across species, functional groups, and forest types is increasing. For many species, increasing levels of competition (i.e., density) is related to a decrease in an individual tree's drought resistance, recovery, and resilience (Linares et al. 2010; Kohler et al. 2010; Lebourgeois et al. 2014). Other studies suggest that the relationships among overall resilience, competition, and climate are not straightforward. For example, in plantation-origin red pine (Pinus resinosa Ait.) stands in Minnesota, resistance to drought at the stand level was dependent upon an interaction between stand age/tree size and density (D'Amato et al. 2013). The authors observed that thinning to low densities at a young age (49 years) conferred increased drought resistance while the reverse was observed during a drought event occurring at an older age (76 years). Variability in the effects of density or competition on climategrowth relationships and, more specifically, response to drought have been observed in natural and plantation-origin forests in Europe (e.g., Gea-Izquierdo et al. 2009; Lebourgeois et al. 2014; Sánchez-Salguero et al. 2015) and, although to a far lesser extent, North America (e.g., McDowell et al. 2006; D'Amato et al. 2013; Keyser and Brown 2014). Results from these studies suggest that the development of thinning prescriptions intended to increase resiliency to extreme climatic events, including drought, must account for variation across species, emergent stand properties, and environmental conditions.

The southern Appalachian-Cumberland Region encompasses $\sim 25.2$ million hectares in the southeastern USA. These forests possess some of the highest level of tree diversity outside of the tropics (Keyser et al. 2014), and, although diverse, the broadleaved deciduous forests that characterize the forested landscapes of this area are dominated by ecologically and economically valuable oak species (Fei et al. 2011; Keyser et al. 2014). Sustaining the growth and productivity of oak species, in particular, is critical to the long-term production of critical ecosystem goods and services provided by these mixed-deciduous broadleaved forests (e.g., McShae et al. 2007; Keyser et al. 2014). Although oaks are considered tolerant of drought (Abrams 1990), reduced growth due to drought predisposes oaks to mortality (Jenkins and Pallardy 1995; Pedersen 1998). In this study, we examined how tree density, stem size, and site productivity influence tree-level growth during drought years for the predominant oak species across southern Appalachian mixed-hardwood forests. Specifically, we hypothesized that (1) the ability to resist and recover from drought will be positively associated with stem size; (2) as stand density increases, trees will be increasingly susceptible to drought-related reductions in tree growth (i.e., display lower resistance to drought) and have a lesser ability to recover from drought; and (3) the ability to resist and recover from drought will be positively associated with estimates of site productivity (i.e., site index). Quantitative information regarding the response of tree growth to drought across structural and environmental gradients will provide information as to whether modifying stand structure via silvicultural thinning can mitigate the deleterious effects of drought on tree growth as well as provide information that will aid in the identification of stands most susceptible to drought-induced reductions in growth. 


\section{Methods}

\subsection{Study area}

This study uses data collected as part of a study examining the growth and yield of mixed-hardwood stands in response to thinning across the southern Appalachians. During the dormant season of 1974/1975, 62 permanent plots ranging in size from 0.06 to 0.1 ha were established in upland hardwood stands throughout the Blue Ridge and northern Ridge and Valley provinces of the southern Appalachian Mountains. Plots were located in naturally regenerated stands that originated as a result of heavy cutting between 1916 and 1955 (Harrison et al. 1986) in the mountains of northern Georgia $(n=3)$, western North Carolina $(n=41)$, eastern Tennessee $(n=11)$, and southwestern Virginia $(n=7)$. Plots were located in a variety of topographic positions, with slopes between 6 and $65 \%$ and altitudes that ranged from 600 to $1350 \mathrm{~m}$. All plots were established in even-aged stands of mixed-species composition, with oak species generally constituting the greatest proportion of plot basal area $\left(\mathrm{BA} ; \mathrm{m}^{2} / \mathrm{ha}\right)$. The geographic and altitudinal gradients associated with the study area resulted in variability in climate and soils. Soils were generally typic dystrochrepts and typic and humic hapludults derived from arkose sandstone, granite gneiss, mica gneiss, and mica schist (Beck 1983). Across the study area, 30-year mean annual temperature varied from $11.6^{\circ} \mathrm{C}$ in Virginia to $15.1^{\circ} \mathrm{C}$ in Georgia (http://www.ncdc.noaa.gov/cag/time-series/us). Precipitation across the study area is generally evenly distributed throughout the year and increases with elevation (McNab 2011). Thirty-year mean annual precipitation varied between $1119 \mathrm{~mm}$ in Virginia and $1406 \mathrm{~mm}$ in North Carolina (http://www.ncdc.noaa.gov/cag/time-series/us).

\subsection{Data collection}

At the time of plot establishment, all live trees $>2.54 \mathrm{~cm}$ in diameter at breast height (DBH $(\mathrm{cm}) ; 1.37 \mathrm{~m}$ above ground line) within each plot were tagged, and species and DBH were recorded. During the initial inventory, one increment core from $0.3 \mathrm{~m}$ above ground line along with total tree height (m) was obtained from six dominant/codominant trees per plot. Using age and height data, an estimate of site index (SI (base-age 50)) for each of the six trees per plot was calculated. Site index for non-oak species was converted to that of white oak using Doolittle's (1958) conversion equations while SI for oak species was computed according to Olson (1959). Plotlevel SI was calculated as the average SI of the six sample trees. Immediately following the initial inventory (dormant season $1974 / 1975$ ), the 62 plots received a low thinning to a residual BA that was at least $6 \mathrm{~m}^{2} /$ ha less than the prethinning BA. To eliminate any potential edge effect, a 20-m buffer was treated in a similar manner around each plot. Remeasurement of all plots occurred during the dormant season every 5 years following thinning through 2005. During each inventory, $\mathrm{DBH}$ of all the live trees tagged in the original inventory was recorded. Although unthinned control plots were established as part of the original (1970s) study, sample size was low $(n=13)$ relative to the thinned plots $(n=62)$. In addition, unthinned plots were geographically clustered in eastern Tennessee, generally contained older and larger trees, and were remeasured only sporadically throughout the 1975 2005 time period. A limitation of the current study, consequently, is that only data from thinned plots were utilized.

During the fall/winter of 2010 , one increment core was collected from three to eight dominant/codominant trees per plot. Increment cores were collected at approximately $1.37 \mathrm{~m}$ above ground line and along the contour of the slope. Initially, five dominant/codominant trees per plot were randomly selected for coring. Oak species were the preferred sample species, with other broadleaved deciduous species selected only when oaks were unavailable. During the collection of increment cores, a portion of the preselected sample trees were dead or possessed serious defect/damage. In those cases, alternative dominant/codominant oak trees were selected for sampling. In some cases, no suitable substitute sample tree(s) existed, hence, the reduction in sample trees from the original five to three on a subsample of the plots. When sampling on a given plot was reduced due to lack of adequate sample trees, additional cores were obtained from suitable sample trees on subsequent plot(s). Cores were dried, mounted, and sanded with progressively finer sandpaper until cell structure was clearly visible. Rings were visually crossdated, and radial growth was measured to the nearest $0.001 \mathrm{~mm}$ using a linearly controlled stage and microscope attached to a digital encoder (Velmex, Inc.). Accuracy of visual crossdating was supported statistically using the program COFECHA (Holmes 1983). Tight rings, indistinct ring boundaries, and/or broken cores resulted in poor crossdating on a subsample of cores. Consequently, increment cores from 11 plots were eliminated from the dataset resulting in 233 cores from 8 species: white oak (50 cores from 18 plots), chestnut oak (54 cores from 24 plots), scarlet oak (Quercus coccinea Muenchh.; 13 cores from 10 plots), northern red oak (Quercus rubra L.; 91 cores from 34 plots), and black oak (Quercus velutnia Lam.; 25 cores from 17 plots). Crossdated ring-width chronologies were converted to chronologies of annual inside bark basal area increment (BAI; $\mathrm{cm}^{2} /$ year) assuming circularity for each sample tree. Specifically, BAI was calculated as

$B A I=\pi\left(r_{t}^{2}-r_{t-1}^{2}\right)$,

where $r$ is the radius of the tree and $t$ is the year of ring formation.

Between the fall/winter of 1974/1975 and 2010, two distinct drought events (1985/6 to 1988 and 2006/7 to 2008 ; Table 1) occurring across the entire study area (all 62 plots) were recorded. Drought events were identified using the 
Table 1 Mean Palmer Drought Severity Index values during the months of May, June, and July (PDSIMJJ) during the 2 years preceding a drought (PDSIMJJ $_{\text {pre }}$ ), during the drought (PDSIMJJ $_{\text {drought }}$ ), and during the 2 years post-drought $\left(\right.$ PDSIMJJ $\left._{\text {post }}\right)$

\begin{tabular}{|c|c|c|c|c|c|c|}
\hline Location & $\begin{array}{l}\text { Pre-drought } \\
\text { years }\end{array}$ & PDSIMJJ $_{\text {pre }}$ & $\begin{array}{l}\text { Drought } \\
\text { years }\end{array}$ & PDSIMJJ drought $_{\text {d }}$ & $\begin{array}{l}\text { Post-drought } \\
\text { years }\end{array}$ & PDSIMJJ $_{\text {post }}$ \\
\hline & Drought 1 & & & & & \\
\hline Georgia & 1984-1985 & 1.17 & 1986-1988 & -3.52 & 1989-1990 & 2.10 \\
\hline $\begin{array}{l}\text { North } \\
\text { Carolina }\end{array}$ & 1983-1984 & 1.28 & 1985-1988 & -3.34 & 1989-1990 & 2.03 \\
\hline Tennessee & 1983-1984 & 0.75 & 1985-1988 & -3.59 & 1989-1990 & 2.29 \\
\hline \multirow[t]{2}{*}{ Virginia } & 1984-1985 & -0.34 & 1986-1988 & -2.68 & 1989-1990 & 1.04 \\
\hline & Drought 2 & & & & & \\
\hline Georgia & 2004-2005 & 1.02 & 2006-2008 & -3.52 & 2009-2010 & -1.23 \\
\hline $\begin{array}{l}\text { North } \\
\text { Carolina }\end{array}$ & 2004-2005 & 0.85 & 2006-2008 & -3.12 & 2009-2010 & -0.12 \\
\hline Tennessee & 2005-2006 & -0.44 & 2007-2008 & -3.70 & 2009-2010 & -0.07 \\
\hline Virginia & 2005-2006 & -0.02 & 2007-2008 & -2.67 & 2009-2010 & 0.19 \\
\hline
\end{tabular}

Palmer Drought Severity Index (PDSI) values during the months of May, June, and July (PDSIMJJ), the period when moisture deficit most significantly impacts the current year radial increment of red and white oak species (Speer et al. 2009; LeBlanc and Terrell 2011). A drought event was considered moderate when PDSIMJJ values were $\geq-3.0$ but $<$ -2.0 and severe when PDSIMJJ values were $\geq-4.0$ but $<$ -3.0. All PDSI values were obtained from the National Climatic Data Center (http://www.ncdc.noaa.gov/cag/timeseries/us), with PDSI values specific to each plot's location within its respective State and Climate Division (plots in Georgia were within the North Central Climate Division (CD) 2, plots in North Carolina were with the Southern Mountains CD1, plots in Tennessee were within the Eastern CD1, and plots in Virginia were within the Southwestern Mountains CD6).

\subsection{Data analysis}

We calculated three drought indices according to Lloret et al.

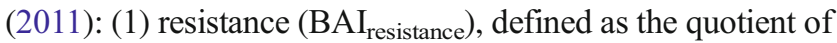
BAI during a drought $\left(\mathrm{BAI}_{\text {drought }}\right)$ and average $\mathrm{BAI} 2$ years prior to a drought $\left(\mathrm{BAI}_{\text {pre }}\right)$; (2) recovery $\left(\mathrm{BAI}_{\text {recovery }}\right)$, defined as the quotient of average BAI 2 years following a drought $\left(\mathrm{BAI}_{\text {post }}\right)$ and $\mathrm{BAI}_{\text {drought }}$; and (3) resilience (BAI $\mathrm{Bresilience}_{\text {e }}$, defined as the quotient of $\mathrm{BAI}_{\text {post }}$ and $\mathrm{BAI}_{\text {pre }}$. When appropriate, $\mathrm{BAI}_{\text {drought }}$ values encompassed multiple years (Table 1). $\mathrm{BAI}_{\text {resistance }}$ values $<1.0$ indicated that BAI during a drought event was less than the average BAI 2 years prior to the drought event while $\mathrm{BAI}_{\text {resistance }}$ values $>1.0$ indicated that BAI during a drought event was greater than the average BAI 2 years prior to the drought. Interpretation of $\mathrm{BAI}_{\text {recovery }}$ and $\mathrm{BAI}_{\text {resilience }}$ values are similar to that of BAI $_{\text {resistance. }}$ Due to the limited sample size, scarlet oak, red maple, and hickory were not analyzed.
For each species and drought event, we used a random coefficients model to examine the effects of density, stem size, and site productivity on $\mathrm{BAI}_{\text {resistance }}, \mathrm{BAI}_{\text {recovery }}$, and $\mathrm{BAI}_{\text {resilience }}$. Due to the hierarchical structure of the data (i.e., trees nested within plots), the plot was considered a random factor. Five candidate models were evaluated: (1) null, or intercept only model; (2) a model with only DBH; (3) a model with only a measure of density; (4) a model with only SI, which is an indirect measure of site productivity; and (5) an additive model with DBH and density and SI. Stem size (i.e., $\mathrm{DBH}$ ) was reconstructed using individual tree BAI values and the initial prethinning DBH value. We chose to use a measure of relative density (RD) in lieu of absolute measures of density (e.g., BA or stems/ha) because plots were of mixed-species composition and variation in species composition often confounds the effects of absolute density on growth (Roach 1977; Stout and Nyland 1986). Relative density was calculated as the quotient of stand density index (SDI) (Reineke 1933) during each inventory period and maximum SDI. Maximum SDI values (Keyser 2008) varied by forest type associated with each plot. An information theoretic approach was used to compare the five aforementioned a priori models per species and drought event. Akaike's information criterion adjusted for sample size $\left(\mathrm{AIC}_{\mathrm{c}}\right)$ was used to determine which models most parsimoniously fit the data (lowest AICc). Parameters associated with top-ranked models and any "competitive" models within two AICc units of the best model were considered informative if the $95 \%$ confidence interval did not include zero. Akaike weights $\left(w_{\mathrm{i}}\right)$ were calculated to provide information regarding the strength of evidence for each model (Burnham and Anderson 2002). Plot-level density statistics were obtained from the inventory data most closely associated with a particular drought event. Drought indices were $\ln$ transformed to approximate normality and equalize variance of the residuals. Because models were developed to test for the effects of stem size, density, and site productivity on the three 
drought indices, the models should be considered explanatory as opposed to predictive. All analyses were conducted using SAS version 9.3 (SAS Institute 2011).

\section{Results}

\subsection{Study attributes}

Plot- and individual tree-level attributes varied considerably across species (Table 2, Fig. 1). Over the time period examined in this study (1975-2010), individual tree BAI for northern red, black, chestnut, and white oak was variable, with northern red and black oak generally possessing greater BAI than chestnut and white oak (Fig. 2). Tree-level BAI during both drought events $\left(\mathrm{BAI}_{\text {drought }}\right)$ was greatest for northern red and white oak than for black and chestnut oak (Table 3).

The two drought events recorded between 1975 and 2010 (1985/1986 to 1988 and $2006 / 2007$ to 2008 ; Table 1) were classified as severe in Georgia, North Carolina, and Tennessee and moderate in Virginia. PDSIMJJ drought $_{\text {values ranged from }}$ -3.59 and -2.68 during the first drought and from -3.52 and
-2.67 during the second drought. PDSIMJJ $\mathrm{pre}_{\text {pas }}$ wear normal prior to both the first and second drought, with PDSIMJJ $_{\text {pre }}$ averaging 0.72 and 0.35 , respectively. The 2 years following the first drought were characterized by slightly wet conditions, with PDSIMJJ ${ }_{\text {post }}$ averaging 1.87 compared to the 2 years following the second drought when PDSIMJJ ${ }_{\text {post }}$ was classified as near normal, with PDSIMJJ post $_{\text {averaging }}-0.31$.

\subsection{Drought 1}

During the first drought, the majority of northern red and black oak trees experienced a decline in growth relative to growth 2 years preceding the drought. $\mathrm{BAI}_{\text {resistance }}$ values were $<1.0$ for 55 and $76 \%$ of the northern red and black oak trees sampled, respectively (Fig. 3). In contrast, only $50 \%$ of the chestnut oak and $36 \%$ of the white oak trees sampled possessed $\mathrm{BAI}_{\text {resistance }}$ values $<1.0$ during the first drought event. $\mathrm{BAI}_{\text {resistance }}$ for northern red, chestnut, and white oak resulted in an uninformative model characterized by the null model being the most supported (chestnut oak) or a competitive model within two $\mathrm{AIC}_{\mathrm{C}}$ of the top-ranked model (northern red and white oak) (Table 4). For these species, top-

Table 2 Range of plot- and sample tree-level attributes associated with the analyses of northern red, black, chestnut, and white oak, including plotlevel basal area (BA), relative density (RD), site index (SI; upland oak, base-age 50), individual tree DBH, and individual tree age

\begin{tabular}{|c|c|c|c|c|c|c|c|c|}
\hline & $\begin{array}{l}\text { Mean } \\
\text { Drought } 1\end{array}$ & Standard deviation & Minimum & Maximum & $\begin{array}{l}\text { Mean } \\
\text { Drought } 2\end{array}$ & Standard deviation & Minimum & Maximum \\
\hline \multicolumn{9}{|c|}{ Northern red oak } \\
\hline $\mathrm{BA}\left(\mathrm{m}^{2} / \mathrm{ha}\right)$ & 19.1 & 6.0 & 9.2 & 35.1 & 26.9 & 8.2 & 13.1 & 55.1 \\
\hline $\mathrm{RD}(\%)$ & 0.34 & 0.11 & 0.16 & 0.59 & 0.44 & 0.14 & 0.21 & 0.83 \\
\hline $\mathrm{DBH}(\mathrm{cm})$ & 32.3 & 7.1 & 11.6 & 52.6 & 41.7 & 8.8 & 14.0 & 65.0 \\
\hline $\mathrm{SI}(\mathrm{m})$ & 24.1 & 2.2 & 18.0 & 29.3 & 24.1 & 2.2 & 18.0 & 29.3 \\
\hline Age (yrs) & 44 & 12 & 18 & 70 & 64 & 12 & 38 & 90 \\
\hline \multicolumn{9}{|l|}{ Black oak } \\
\hline $\mathrm{BA}\left(\mathrm{m}^{2} / \mathrm{ha}\right)$ & 17.1 & 5.2 & 9.2 & 25.9 & 24.3 & 7.2 & 13.1 & 34.7 \\
\hline $\mathrm{RD}(\%)$ & 0.30 & 0.10 & 0.16 & 0.48 & 0.39 & 0.12 & 0.21 & 0.58 \\
\hline $\mathrm{DBH}(\mathrm{cm})$ & 33.9 & 4.5 & 23.3 & 43.3 & 40.7 & 5.4 & 27.2 & 51.9 \\
\hline $\mathrm{SI}(\mathrm{m})$ & 24.6 & 1.8 & 21.3 & 27.7 & 24.6 & 1.8 & 21.3 & 27.7 \\
\hline Age (yrs) & 50 & 9 & 30 & 60 & 70 & 9 & 50 & 80 \\
\hline \multicolumn{9}{|l|}{ Chestnut oak } \\
\hline $\mathrm{BA}\left(\mathrm{m}^{2} / \mathrm{ha}\right)$ & 18.3 & 4.6 & 10.8 & 28.2 & 25.3 & 5.2 & 15.4 & 33.1 \\
\hline $\mathrm{RD}(\%)$ & 0.34 & 0.09 & 0.17 & 0.51 & 0.43 & 0.10 & 0.22 & 0.56 \\
\hline $\mathrm{DBH}(\mathrm{cm})$ & 28.5 & 5.3 & 20.2 & 43.0 & 35.2 & 6.4 & 25.8 & 55.0 \\
\hline $\mathrm{SI}(\mathrm{m})$ & 23.9 & 2.2 & 18.0 & 27.7 & 23.9 & 2.2 & 18.0 & 27.7 \\
\hline Age (yrs) & 44 & 10 & 27 & 68 & 64 & 10 & 47 & 88 \\
\hline \multicolumn{9}{|l|}{ White oak } \\
\hline $\mathrm{BA}\left(\mathrm{m}^{2} / \mathrm{ha}\right)$ & 17.5 & 4.4 & 10.8 & 25.9 & 24.6 & 5.3 & 16.1 & 34.7 \\
\hline $\mathrm{RD}(\%)$ & 0.30 & 0.08 & 0.17 & 0.47 & 0.38 & 0.09 & 0.25 & 0.58 \\
\hline DBH (cm) & 33.1 & 5.5 & 22.5 & 46.3 & 40.7 & 6.8 & 25.9 & 63.8 \\
\hline $\mathrm{SI}(\mathrm{m})$ & 24.7 & 1.7 & 21.6 & 27.7 & 24.7 & 1.7 & 21.6 & 27.7 \\
\hline Age (yrs) & 56 & 7 & 38 & 70 & 76 & 7 & 58 & 90 \\
\hline
\end{tabular}


Fig. 1 Distribution of sample trees by relative density class (a), diameter class (b), and site index class $(\mathbf{c})$. Relative density classes were (1) $<0.20,(2) \geq 0.20$ and $<0.30$, (3) $\geq 0.30$ and $<0.40$, (4) $\geq 0.40$ and $<0.50,(5) \geq 0.50$ and $<0.60$, and $(6) \geq 0.60$. Site index classes were $(1) \geq 18.0$ and $<20.0$, (2) $\geq 20.0$ and $<22.0,(3) \geq 22.0$ and $<24.0,(4) \geq 24.0$ and $<26.0$, (5) $\geq 26.0$ and $<28.0$, and (6) $\geq 28.0$ and $<30.0$ (a)

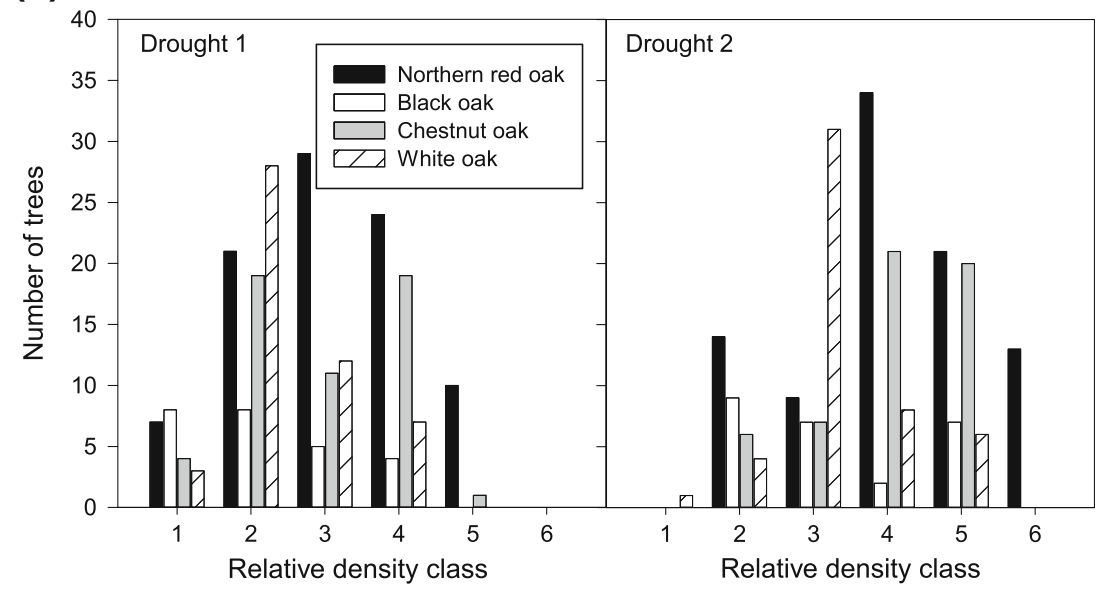

(b)

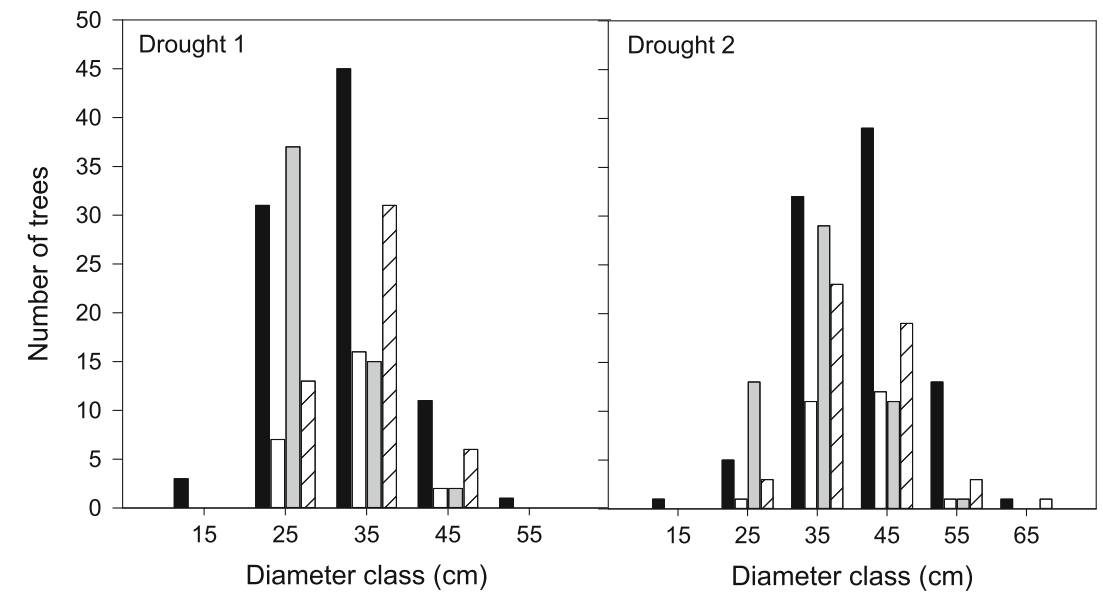

(c)

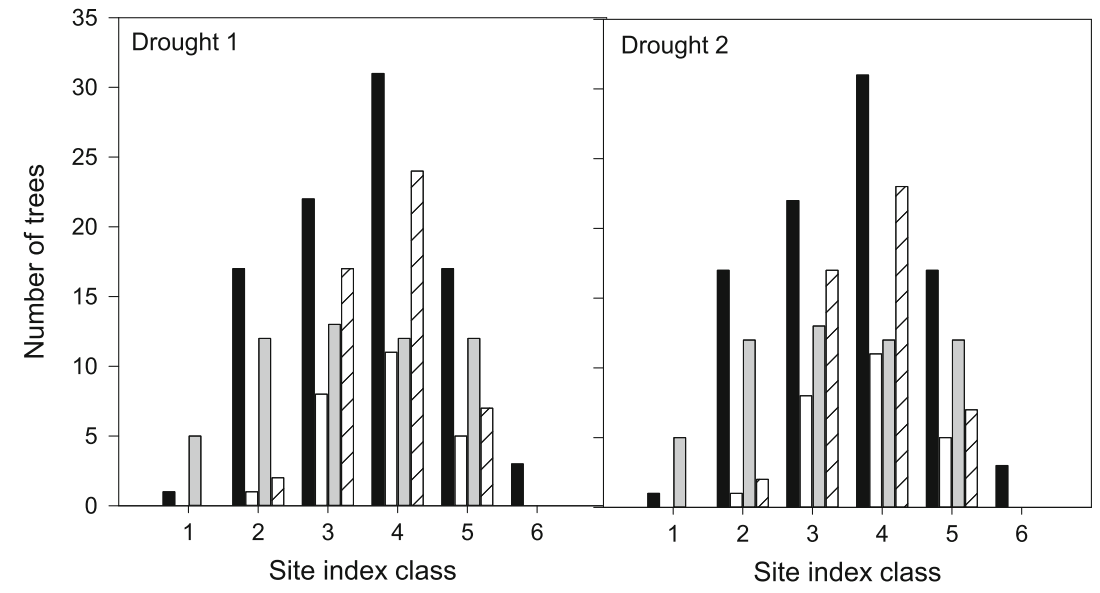

ranked models as well as models within two $\mathrm{AIC}_{\mathrm{C}}$ of the topranked models contained uninformative covariates (i.e., $95 \%$ confidence intervals that contained zero), suggesting that these variables had little effect on $\mathrm{BAI}_{\text {resistance. }}$ For black oak, the most parsimonious model contained $\mathrm{RD}$, which was 5.3 $\mathrm{AIC}_{\mathrm{C}}$ units from the next best model (Table 4). The parameter estimate associated with RD (95\% confidence interval) was $-0.9158(-1.3812,-0.4504)$, suggesting that the $\mathrm{BAI}_{\text {resistance }}$ of black oak during the first drought decreased as RD increased.

Substantial variability in $\mathrm{BAI}_{\text {recovery }}$ among the oak species was observed after the first drought event. For the majority of 
(a)

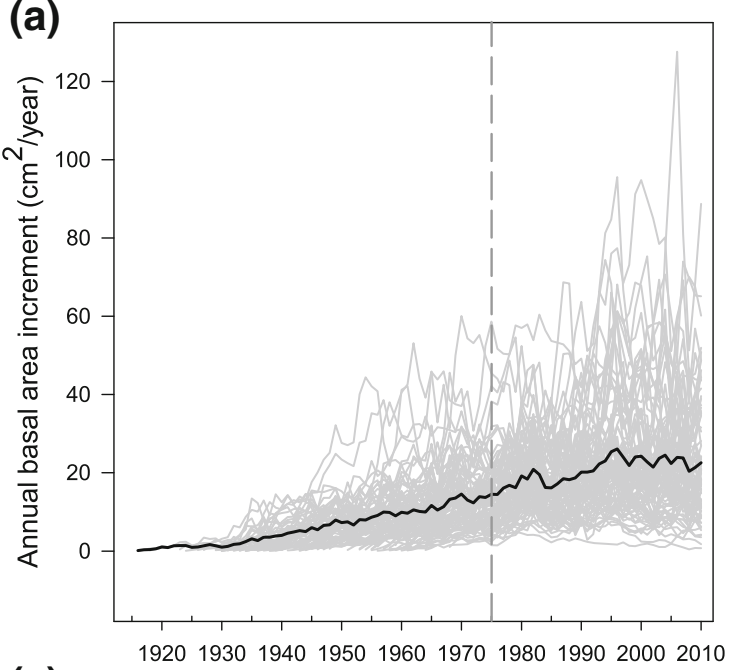

(c)

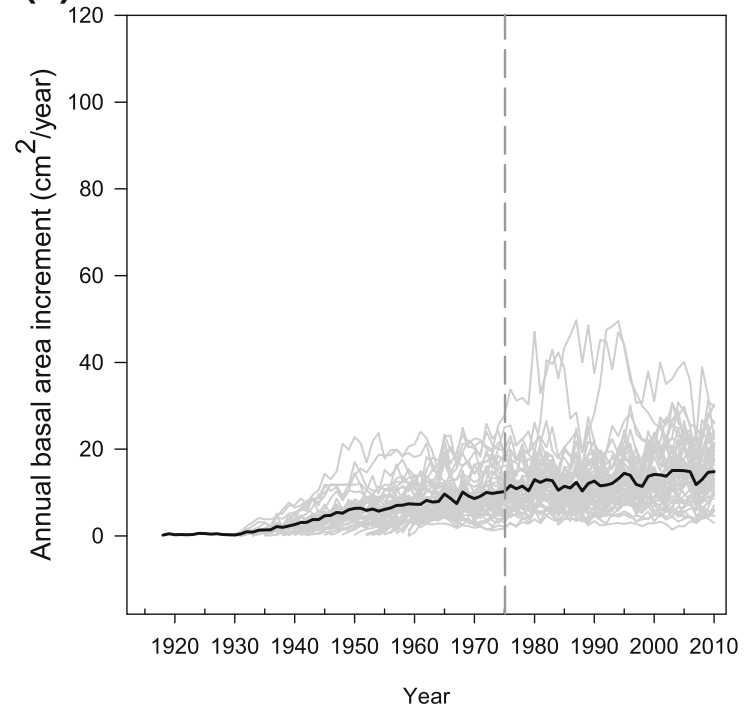

Fig. 2 Basal area increment ( $\mathrm{cm}^{2} /$ year) for northern red (a), black (b), chestnut (c), and white oak (d). Gray lines represent the individual tree BAI chronologies while the black line represents average BAI

northern red, chestnut, and white oak trees sampled, growth during the 2 years after drought had surpassed average growth during the drought (Fig. 3). For black oak, however,

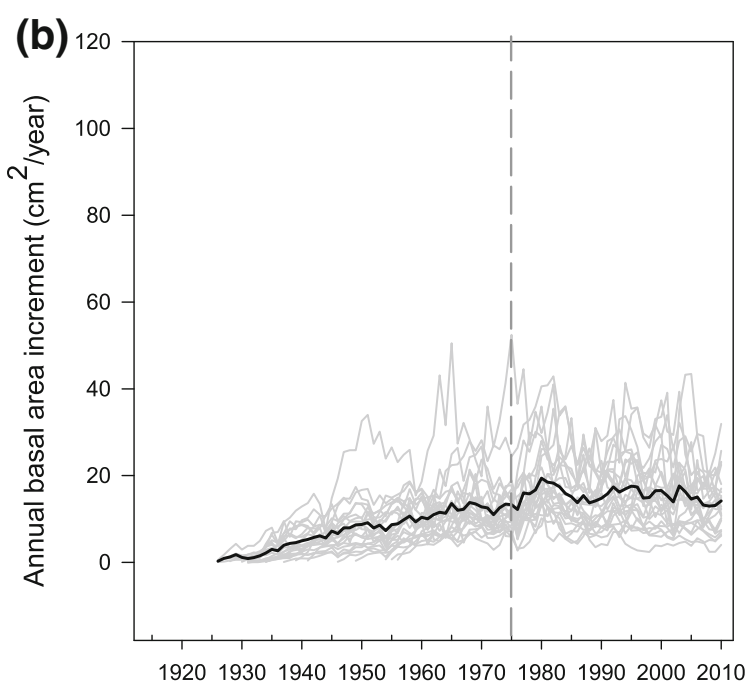

(d)

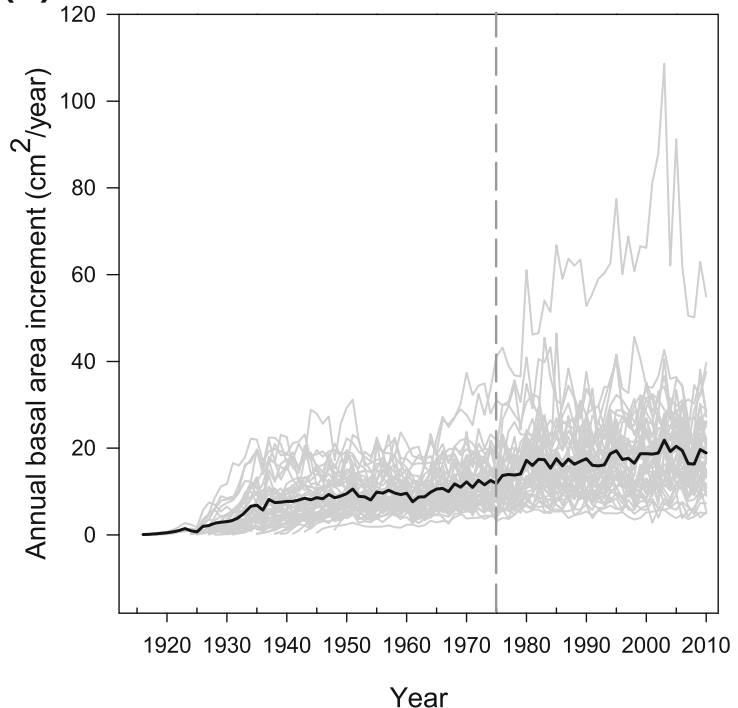

chronology for the respective species. Dashed vertical line indicates year of thinning (fall/winter 1974/1975)

$\mathrm{BAI}_{\text {recovery }}$ values for $56 \%$ of the trees sampled remained $<1.0$. For northern red oak, the model best supported by the data (4.6 $\mathrm{AIC}_{\mathrm{C}}$ units from the next best model) was the
Table 3 Mean (standard deviation) annual basal area increment (BAI) calculated during the 2 years preceding drought $\left(\mathrm{BAI}_{\text {pre }}\right)$, during drought $\left(\mathrm{BAI}_{\text {drought }}\right)$, and during the 2 years following drought (BAI $\mathrm{Bost})$

\begin{tabular}{lllllll}
\hline Species & $\begin{array}{l}\mathrm{BAI}_{\text {pre }} \\
\left(\mathrm{cm}^{2} / \text { year }\right)\end{array}$ & $\begin{array}{l}\mathrm{BAI}_{\text {drought }} \\
\text { Drought } 1\end{array}$ & $\begin{array}{l}\left.\mathrm{cm}^{2} / \text { year }\right) \\
\left(\mathrm{cm}^{2} / \text { year }\right)\end{array}$ & $\begin{array}{l}\mathrm{BAI}_{\text {pre }} \\
\left(\mathrm{cm}^{2} / \text { year }\right) \\
\text { Drought } 2\end{array}$ & $\begin{array}{l}\mathrm{BAI}_{\text {drought }} \\
\left(\mathrm{cm}^{2} / \text { year }\right)\end{array}$ & $\begin{array}{l}\mathrm{BAI}_{\text {post }} \\
\left(\mathrm{cm}^{2} / \text { year }\right)\end{array}$ \\
\hline Northern red oak & 17.65 & 17.57 & 19.44 & 22.97 & 22.65 & 22.03 \\
Black oak & $(9.05)$ & $(9.68)$ & $(10.82)$ & $(14.88)$ & $(14.76)$ & $(14.77)$ \\
Chestnut oak & 16.11 & 14.56 & 14.47 & 14.94 & 13.43 & 13.64 \\
& $(8.00)$ & $(6.10)$ & $(6.40)$ & $(7.26)$ & $(5.41)$ & $(6.21)$ \\
White oak & 11.60 & 11.31 & 12.38 & 15.17 & 13.14 & 14.76 \\
& $(6.94)$ & $(6.63)$ & $(6.77)$ & $(7.44)$ & $(6.03)$ & $(6.85)$ \\
& 16.21 & 16.86 & 17.28 & 19.63 & 17.07 & 19.31 \\
& $(8.77)$ & $(9.31)$ & $(8.85)$ & $(11.09)$ & $(8.32)$ & $(9.47)$ \\
\hline
\end{tabular}



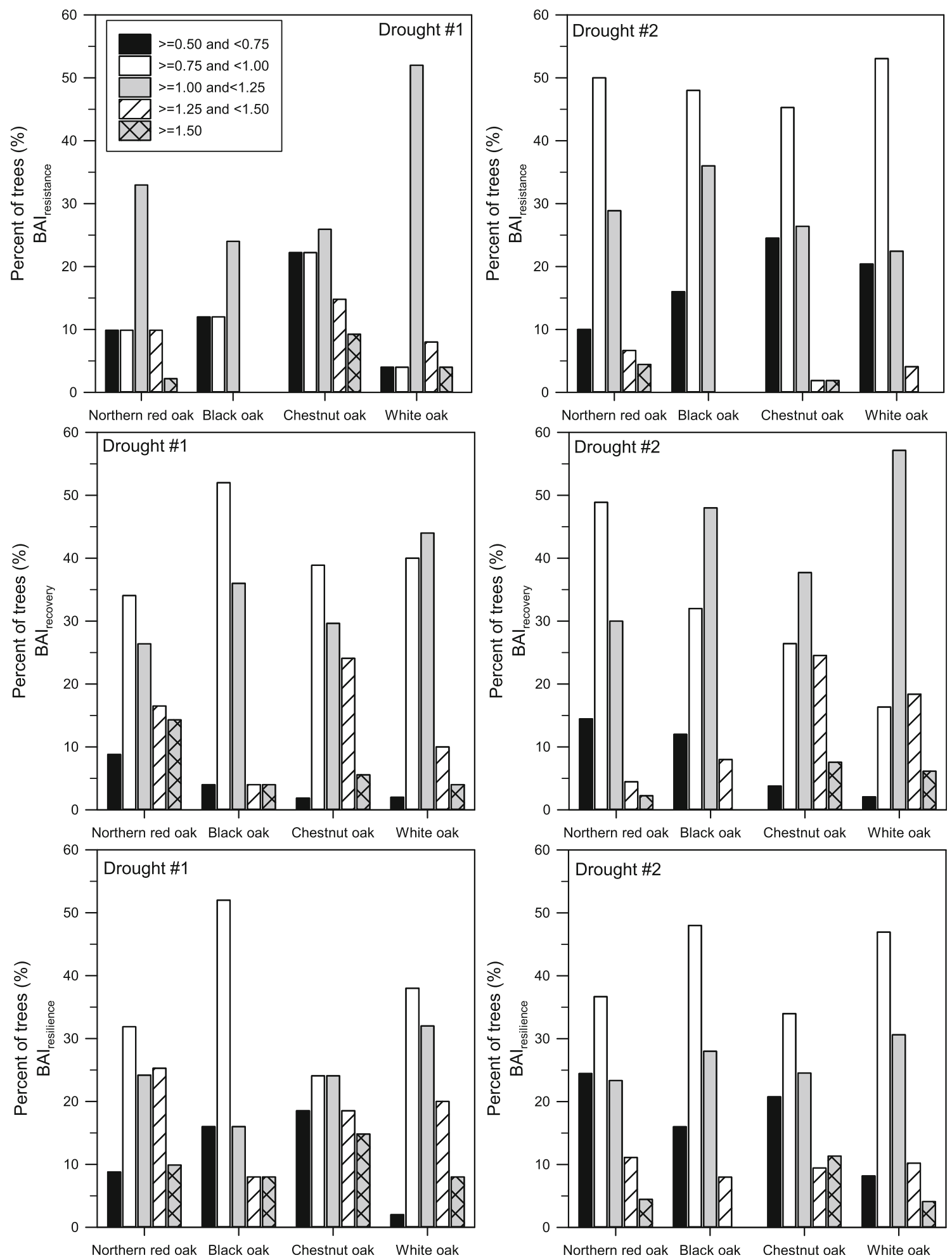

Fig. 3 Percent of sample trees by species and drought event by BAI

, $\mathrm{BAI}_{\text {recovery, }}$ and $\mathrm{BAI}_{\text {resilience }}$ category

additive model that included DBH, RD, and SI (Table 4). Although the DBH parameter was uninformative in this mod$\mathrm{el}$, the SI and RD parameters were informative and estimated to be $0.0424(0.0147,0.0701)$ and $0.9377(0.3966,1.4787)$, respectively. This suggests that the $\mathrm{BAI}_{\text {recovery }}$ of northern red

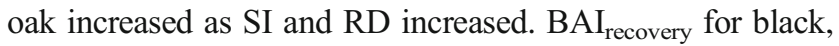
chestnut, and white oak produced an uninformative model characterized by the null model being most supported by the 
Table 4 Model fit statistics associated with $\mathrm{BAI}_{\text {resistance, }} \mathrm{BAI}_{\text {recovery}}$, and $\mathrm{BAI}_{\text {resilience }}$ during the first drought for northern red oak, black oak, chestnut oak, and white oak

\begin{tabular}{|c|c|c|c|c|c|c|c|c|c|c|c|}
\hline \multirow[b]{2}{*}{ Northern red oak } & \multicolumn{4}{|c|}{$\begin{array}{l}\mathrm{AIC}_{\mathrm{C}} \quad \Delta \mathrm{AIC}_{\mathrm{C}} \quad w_{\mathrm{i}} \\
\text { Drought } 1-B A I_{\text {resistance }}\end{array}$} & \multicolumn{4}{|c|}{$\begin{array}{l}\mathrm{AIC}_{\mathrm{C}} \quad \Delta \mathrm{AIC}_{\mathrm{C}} \quad w_{\mathrm{i}} \\
\text { Drought } 1-\text { BAI }_{\text {recovery }}\end{array}$} & \multicolumn{3}{|c|}{$\begin{array}{l}\mathrm{AIC}_{\mathrm{C}} \quad \Delta \mathrm{AIC}_{\mathrm{C}} \quad w_{\mathrm{i}} \\
\text { Drought } 1-B A I_{\text {resilience }}\end{array}$} \\
\hline & & & & & & & & & & & \\
\hline $\mathrm{RD}$ & -28.5 & 0.0 & 0.29 & $\mathrm{DBH}+\mathrm{RD}^{\mathrm{b}}+\mathrm{SI}^{\mathrm{b}}$ & 4.6 & 0.0 & 0.88 & SI & 47.4 & 0.0 & 0.34 \\
\hline Null & -28.2 & 0.3 & 0.25 & $\mathrm{RD}^{\mathrm{b}}$ & 9.2 & 4.6 & 0.09 & Null & 48.2 & 0.8 & 0.23 \\
\hline $\mathrm{DBH}$ & -27.9 & 0.6 & 0.22 & $\mathrm{SI}^{\mathrm{b}}$ & 11.8 & 7.2 & 0.02 & $\mathrm{RD}$ & 48.4 & 1.0 & 0.21 \\
\hline SI & -26.7 & 1.8 & 0.12 & Null & 14.8 & 10.2 & 0.01 & $\mathrm{DBH}+\mathrm{RD}+\mathrm{SI}^{\mathrm{b}}$ & 49.1 & 1.7 & 0.15 \\
\hline $\mathrm{DBH}+\mathrm{RD}+\mathrm{SI}$ & -26.7 & 1.8 & 0.12 & $\mathrm{DBH}$ & 15.9 & 11.3 & 0.00 & $\mathrm{DBH}$ & 50.4 & 3.0 & 0.08 \\
\hline \multicolumn{12}{|l|}{ Black oak } \\
\hline $\mathrm{RD}^{\mathrm{a}}$ & -32.0 & 0.0 & 0.93 & Null & 13.2 & 0.0 & 0.50 & $\mathrm{RD}$ & 23.3 & 0.0 & 0.43 \\
\hline $\mathrm{DBH}+\mathrm{RD}^{\mathrm{a}}+\mathrm{SI}$ & -26.7 & 5.3 & 0.07 & SI & 15.3 & 2.1 & 0.18 & Null & 23.8 & 0.5 & 0.34 \\
\hline Null & -20.4 & 11.6 & 0.00 & $\mathrm{RD}$ & 15.5 & 2.3 & 0.16 & SI & 26.3 & 3.0 & 0.10 \\
\hline $\mathrm{DBH}$ & -19.1 & 12.9 & 0.00 & $\mathrm{DBH}$ & 15.6 & 2.4 & 0.15 & $\mathrm{DBH}$ & 26.4 & 3.1 & 0.09 \\
\hline SI & -17.6 & 14.4 & 0.00 & $\mathrm{DBH}+\mathrm{RD}+\mathrm{SI}$ & 20.2 & 7.0 & 0.02 & $\mathrm{DBH}+\mathrm{RD}^{\mathrm{a}}+\mathrm{SI}$ & 27.8 & 4.5 & 0.05 \\
\hline \multicolumn{12}{|l|}{ Chestnut oak } \\
\hline Null & 10.2 & 0.0 & 0.42 & Null & 5.5 & 0.0 & 0.40 & Null & 58.0 & 0.0 & 0.51 \\
\hline SI & 11.6 & 1.4 & 0.21 & SI & 6.3 & 0.8 & 0.27 & $\mathrm{DBH}$ & 60.2 & 2.2 & 0.17 \\
\hline $\mathrm{DBH}$ & 11.9 & 1.7 & 0.18 & $\mathrm{RD}$ & 7.1 & 1.6 & 0.18 & SI & 60.3 & 2.3 & 0.16 \\
\hline $\mathrm{RD}$ & 12.0 & 1.8 & 0.17 & $\mathrm{DBH}$ & 7.7 & 2.2 & 0.13 & $\mathrm{RD}$ & 60.4 & 2.4 & 0.15 \\
\hline $\mathrm{DBH}+\mathrm{RD}+\mathrm{SI}$ & 15.4 & 5.2 & 0.03 & $\mathrm{DBH}+\mathrm{RD}+\mathrm{SI}$ & 10.9 & 5.4 & 0.03 & $\mathrm{DBH}+\mathrm{RD}+\mathrm{SI}$ & 65.1 & 7.1 & 0.01 \\
\hline \multicolumn{12}{|l|}{ White oak } \\
\hline $\mathrm{RD}$ & -25.1 & 0.0 & 0.40 & Null & -18.6 & 0.0 & 0.57 & $\mathrm{DBH}$ & -3.3 & 0.0 & 0.48 \\
\hline Null & -24.5 & 0.6 & 0.29 & $\mathrm{RD}$ & -16.7 & 1.9 & 0.22 & Null & -1.9 & 1.4 & 0.24 \\
\hline SI & -23.1 & 2.0 & 0.15 & $\mathrm{DBH}$ & -16.4 & 2.2 & 0.19 & $\mathrm{RD}$ & -0.2 & 3.1 & 0.10 \\
\hline $\mathrm{DBH}$ & -22.6 & 2.5 & 0.11 & $\mathrm{DBH}+\mathrm{RD}+\mathrm{SI}$ & -12.1 & 6.5 & 0.02 & SI & -0.2 & 3.1 & 0.10 \\
\hline $\mathrm{DBH}+\mathrm{RD}+\mathrm{SI}$ & -20.8 & 4.3 & 0.05 & SI & 16.2 & 34.8 & 0.00 & $\mathrm{DBH}+\mathrm{RD}+\mathrm{SI}$ & 0.5 & 3.8 & 0.07 \\
\hline
\end{tabular}

DBH is tree-level diameter at breast height $(\mathrm{cm}), \mathrm{RD}$ is plot-level relative density $(\%)$, and SI is plot-level site index $(\mathrm{m}) . \Delta \mathrm{AIC}_{\mathrm{C}}$ refers to the change in $\mathrm{AIC}_{\mathrm{C}}$ compared to the best overall model (i.e., the model corresponding to the lowest $\mathrm{AIC}_{\mathrm{C}}$ ), and $w_{\mathrm{i}}$ is Akaike weight.

${ }^{a}$ Informative (i.e., $95 \%$ confidence interval that does not contain zero) and negative parameter estimate

${ }^{\mathrm{b}}$ Informative and positive parameter estimate

data (Table 4). For chestnut and white oak, models containing either SI or RD were within two AICc units of the null; however, these models contained uninformative parameters.

With the exception of black oak, the majority of northern red, chestnut, and white oak trees sampled possessed $\mathrm{BAI}_{\text {resilience }}$ values $\geq 1.0$, indicating that average growth 2 years following the first drought had equaled or surpassed average growth 2 years preceding the drought (Fig. 3). For black oak, however, $68 \%$ of the trees sampled possessed $\mathrm{BAI}_{\text {resilience }}$ values $<1.0$. $\mathrm{BAI}_{\text {resilience }}$ generated an uninformative model for black, chestnut, and white oak, with the null model being the most supported by the data for chestnut oak and within two $\mathrm{AIC}_{\mathrm{C}}$ units of the top-ranked model for black and white oak (Table 4). For black and white oak, the top-ranked models contained uninformative parameters for RD and DBH, respectively. For northern red oak, the model most supported by the data as well as the third ranked model (1.0 AICc units from the top-ranked model) contained uninformative SI and RD parameters. Although the additive model (1.7 AICc units from the top-ranked model) contained uninformative DBH and $\mathrm{RD}$ parameters, the SI parameter was informative and estimated to be $0.0335(0.0005,0.0665)$, providing weak support (i.e., low Akaike weight values) that SI may have had a slight positive effect on the $\mathrm{BAI}_{\text {resilience }}$ of northern red oak during the first drought.

\subsection{Drought 2}

During the second drought, the vast majority of trees sampled, regardless of species, experienced a decline in growth relative to that observed during the 2 years preceding drought. Overall, 60, 64, 70, and $73 \%$ of the northern red, black, chestnut, and white oak trees sampled possessed $\mathrm{BAI}_{\text {resistance }}$ values $<1.0$, respectively (Fig. 3). For northern red oak, the $\mathrm{BAI}_{\text {resistance }}$ model most supported by the data included only SI (2.5 $\mathrm{AIC}_{\mathrm{C}}$ units from the next best model) (Table 5). The parameter estimate associated with SI was $0.0216(0.0019$, 


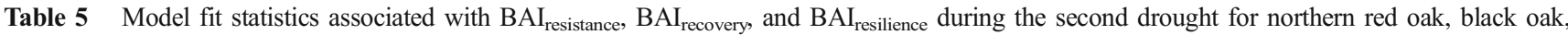
chestnut oak, and white oak

\begin{tabular}{|c|c|c|c|c|c|c|c|c|c|c|c|}
\hline & $\mathrm{AIC}_{\mathrm{C}}$ & $\Delta \mathrm{AIC}_{\mathrm{C}}$ & $w_{\mathrm{i}}$ & & $\mathrm{AIC}_{\mathrm{C}}$ & $\Delta \mathrm{AIC}_{\mathrm{C}}$ & $w_{\mathrm{i}}$ & & $\mathrm{AIC}_{\mathrm{C}}$ & $\Delta \mathrm{AIC}_{\mathrm{C}}$ & $w_{\mathrm{i}}$ \\
\hline Northern red oak & \multicolumn{4}{|c|}{ Drought $2-B A I_{\text {resistance }}$} & \multicolumn{4}{|c|}{ Drought $2-B A I_{\text {recovery }}$} & \multicolumn{3}{|c|}{ Drought $2-B A I_{\text {resilience }}$} \\
\hline $\mathrm{SI}^{\mathrm{b}}$ & -27.2 & 0.0 & 0.63 & $\mathrm{SI}^{\mathrm{a}}$ & -16.4 & 0.0 & 0.76 & Null & 26.0 & 0.0 & 0.44 \\
\hline Null & -24.7 & 2.5 & 0.18 & $\mathrm{DBH}+\mathrm{RD}+\mathrm{SI}^{\mathrm{a}}$ & -13.0 & 3.4 & 0.14 & $\mathrm{RD}$ & 27.2 & 1.2 & 0.24 \\
\hline $\mathrm{DBH}$ & -22.9 & 4.3 & 0.07 & Null & -11.1 & 5.3 & 0.05 & SI & 28.1 & 2.1 & 0.15 \\
\hline $\mathrm{RD}$ & -22.6 & 4.6 & 0.06 & $\mathrm{RD}$ & -10.4 & 6.3 & 0.03 & $\mathrm{DBH}$ & 28.2 & 2.2 & 0.15 \\
\hline $\mathrm{DBH}+\mathrm{RD}+\mathrm{SI}$ & -22.5 & 4.7 & 0.06 & $\mathrm{DBH}$ & -9.0 & 7.4 & 0.02 & $\mathrm{DBH}+\mathrm{RD}+\mathrm{SI}$ & 31.6 & 5.6 & 0.03 \\
\hline \multicolumn{12}{|l|}{ Black oak } \\
\hline $\mathrm{DBH}^{\mathrm{a}}$ & -10.3 & 0.0 & 0.80 & Null & -10.2 & 0.0 & 0.48 & $\mathrm{DBH}$ & -2.8 & 0.0 & 0.40 \\
\hline Null & -6.2 & 4.1 & 0.10 & $\mathrm{RD}$ & -8.5 & 1.7 & 0.21 & Null & -1.6 & 1.2 & 0.22 \\
\hline $\mathrm{DBH}^{\mathrm{a}}+\mathrm{RD}+\mathrm{SI}$ & -4.6 & 5.7 & 0.05 & SI & -8.0 & 2.2 & 0.16 & $\mathrm{DBH}^{\mathrm{a}}+\mathrm{RD}+\mathrm{SI}^{\mathrm{a}}$ & -1.3 & 1.5 & 0.19 \\
\hline $\mathrm{RD}$ & -3.5 & 6.8 & 0.03 & $\mathrm{DBH}$ & -7.6 & 2.6 & 0.13 & $\mathrm{RD}$ & 0.1 & 2.9 & 0.09 \\
\hline SI & -3.3 & 7.0 & 0.02 & $\mathrm{DBH}+\mathrm{RD}+\mathrm{SI}$ & -3.7 & 6.5 & 0.02 & SI & 0.2 & 3.0 & 0.09 \\
\hline \multicolumn{12}{|l|}{ Chestnut oak } \\
\hline $\mathrm{DBH}$ & -12.5 & 0.0 & 0.45 & Null & -15.7 & 0.0 & 0.49 & Null & 27.2 & 0.0 & 0.34 \\
\hline Null & -11.2 & 1.3 & 0.23 & SI & -13.6 & 2.1 & 0.17 & $\mathrm{DBH}$ & 27.2 & 0.0 & 0.34 \\
\hline $\mathrm{RD}$ & -10.2 & 2.3 & 0.14 & $\mathrm{RD}$ & -13.5 & 2.2 & 0.16 & $\mathrm{RD}$ & 28.5 & 1.3 & 0.18 \\
\hline SI & -9.3 & 3.2 & 0.09 & DBH & -13.4 & 2.3 & 0.16 & SI & 29.5 & 2.3 & 0.11 \\
\hline $\mathrm{DBH}+\mathrm{RD}+\mathrm{SI}$ & -9.3 & 3.2 & 0.09 & $\mathrm{DBH}+\mathrm{RD}+\mathrm{SI}$ & -8.8 & 6.9 & 0.02 & $\mathrm{DBH}+\mathrm{RD}+\mathrm{SI}$ & 31.3 & 4.1 & 0.04 \\
\hline \multicolumn{12}{|l|}{ White oak } \\
\hline Null & -26.8 & 0.0 & 0.42 & Null & -22.4 & 0.0 & 0.48 & Null & -10.6 & 0.0 & 0.35 \\
\hline $\mathrm{DBH}$ & -25.6 & 1.2 & 0.23 & SI & -20.6 & 1.8 & 0.20 & SI & -10.1 & 0.5 & 0.27 \\
\hline SI & -24.9 & 1.9 & 0.16 & DBH & -20.2 & 2.2 & 0.16 & DBH & -9.7 & 0.9 & 0.22 \\
\hline $\mathrm{RD}$ & -24.8 & 2.0 & 0.16 & $\mathrm{RD}$ & -20.0 & 2.4 & 0.15 & $\mathrm{RD}$ & -8.5 & 2.1 & 0.12 \\
\hline $\mathrm{DBH}+\mathrm{RD}+\mathrm{SI}$ & -21.0 & 5.8 & 0.02 & $\mathrm{DBH}+\mathrm{RD}+\mathrm{SI}$ & -15.7 & 6.7 & 0.02 & $\mathrm{DBH}+\mathrm{RD}+\mathrm{SI}$ & -6.2 & 4.4 & 0.04 \\
\hline
\end{tabular}

DBH is tree-level diameter at breast height $(\mathrm{cm}), \mathrm{RD}$ is plot-level relative density $(\%)$, and SI is plot-level site index $(\mathrm{m}) . \Delta \mathrm{AIC}_{\mathrm{C}}$ refers to the change in $\mathrm{AIC}_{\mathrm{C}}$ compared to the best overall model (i.e., the model corresponding to the lowest $\mathrm{AIC}$ ), and $w_{\mathrm{i}}$ is Akaike weight.

${ }^{a}$ Informative (i.e., $95 \%$ confidence interval that does not contain zero) and negative parameter estimate

${ }^{\mathrm{b}}$ Informative and positive parameter estimate

0.04133), suggesting that the $\mathrm{BAI}_{\text {resistance }}$ of northern red oak during the second drought increased as SI increased. For black oak, the most parsimonious $\mathrm{BAI}_{\text {resistance }}$ model contained DBH (4.1 $\mathrm{AIC}_{\mathrm{C}}$ units from the next best model) (Table 5). The parameter estimate associated with $\mathrm{DBH}$ was -0.0156 $(-0.0278,-0.0033)$, suggesting that the $\mathrm{BAI}_{\text {resistance }}$ of black oak decreased as DBH increased. For chestnut and white oak, $\mathrm{BAI}_{\text {resistance }}$ produced an uninformative model, with the null model being the most supported (white oak) or within two $\mathrm{AIC}_{\mathrm{C}}$ values of the top-ranked model (chestnut oak) (Table 5). For chestnut and white oak, all models within two $\triangle \mathrm{AIC}_{\mathrm{C}}$ of the top-ranked model contained uninformative covariates.

The ability of BAI to recover from the second drought varied considerably among the four oak species, with a greater percentage of chestnut and white oak possessing $\mathrm{BAI}_{\text {recovery }}$ values $\geq 1.0$ than northern red and black oak trees (Fig. 3). Overall, $63,44,30$, and $18 \%$ of the northern red, black, chestnut, and white oak trees sampled possessed $\mathrm{BAI}_{\text {recovery }}$ values $<1.0$, respectively. For northern red oak, the most parsimonious model for $\mathrm{BAI}_{\text {recovery }}$ contained $\mathrm{SI}\left(3.4 \mathrm{AIC}_{\mathrm{C}}\right.$ units from the next best model) (Table 5). The parameter estimate associated with SI was $-0.0251(-0.0461,-0.0042)$, suggesting that the ability of northern red oak to recover from the second drought decreased as SI increased. For black, chestnut, and white oak, the best supported model for BAI $\mathrm{Brevery}_{\text {was }}$ the null model (Table 5). Although alternative models were within two $\mathrm{AIC}_{\mathrm{C}}$ units for black and white oak, these models contained uninformative covariates.

During the 2 years following the second drought, the growth of the majority of trees sampled, regardless of species, remained lower relative to growth during the 2 years preceding drought. However, a greater percentage of chestnut and white oak trees possessed $\mathrm{BAI}_{\text {resilience }}$ values $\geq 1.0$ than of northern red and black oak trees (Fig. 3). Overall, 61, 64, 55 , and $55 \%$ of the northern red, black, chestnut, and white oak trees sampled possessed $\mathrm{BAI}_{\text {resilience }}$ values $<1.0$, respectively. $\mathrm{BAI}_{\text {resilience }}$ generated an uninformative model for 
northern red, chestnut, and white oak, with the null model being the best supported model (Table 5). Although models were within two $\mathrm{AIC}_{\mathrm{C}}$ units of the null for these species, the parameters associated with these models were uninformative. For black oak, the top-ranked model contained DBH; however, DBH was an uninformative parameter in this singular model. The third ranked model for black oak (1.5 AICc units from the top-ranked model and 0.3 units from the null), although possessing low strength of evidence (i.e., low Akaike weight values), contained informative parameters for DBH and SI, but not RD. Parameter estimates associated with DBH and SI in this model were $-0.0177(-0.0321,-0.0033)$ and $-0.0537(-0.1013,-0.0062)$, respectively, providing weak evidence that increasing DBH and SI negatively affected the $\mathrm{BAI}_{\text {resilience }}$ of black oak.

\section{Discussion}

We found that resistance, recovery, and resilience to drought varied greatly among the four oak species examined as well as between the two drought events. Previous research suggests that species in the white oak (Leucobalanus) group (e.g., chestnut and white oak) are more resistant and resilient to drought than species in the red oak (Erythrobalanus) group (e.g., northern red and black oak) (LeBlanc and Foster 1992; LeBlanc 1998; Abrams 2003). In this study, the white oak group displayed greater drought resistance during the first drought, but not during the second drought. During the first drought event, $57 \%$ of the trees in the white oak group possessed $\mathrm{BAI}_{\text {resistance }}$ values $\geq 1.0$ compared to $41 \%$ of the trees in the red oak group (Fig. 3). During the second drought, however, only $28 \%$ of the trees in the white oak group possessed $\mathrm{BAI}_{\text {resistance }}$ values $\geq 1.0$ compared to $39 \%$ of the trees in the red oak group. Across both drought events, the proportion of trees possessing $\mathrm{BAI}_{\text {resilience }} \geq 1.0$ was consistently greater in the white oak group than in the red oak group.

We hypothesized that stem size would be positively associated with resistance, recovery, and resilience to drought. In the current study, we found that DBH affected the drought response of black oak during the second drought where, contrary to our hypothesis, DBH had a negative effect on

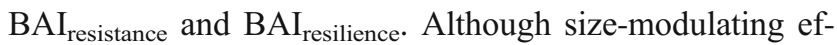
fects on drought response are less abundant for deciduous broadleaved tree species than for coniferous species, the seemingly minor and inconsistent influence of stem size on drought tolerance aligns with previous research results. For example, the effect of increasing stem size on growth during and after drought has been shown to be insignificant (Mérian and Lebourgeois 2011; Zang et al. 2012), positive (Orwig and Abrams 1997; Merlin et al. 2015), and negative (Merlin et al. 2015) for North American and European oak species, including black, white, sessile (Quercus petraea (Matt.)
Liebl.)), and pedunculate (Quercus robur L.) oak. A positive relationship between stem size and drought response is thought to arise from the positive relationship between stem size and the size of an individual tree's root system (BondLamberty et al. 2002; Bolte et al. 2004). As the size and density of an individual's root system increases, so does drought tolerance, as large root systems are able to access soil moisture and nutrients while smaller individuals are not (Bréda et al. 2006). In contrast, the negative effect of stem size on drought tolerance documented for black oak in this study suggests that hydraulic limitations associated with tree architectural characteristics that increase with stem size (e.g., leaf area) (Martin et al. 1998) may negate any positive effects of stem size on drought-related growth (Mencuccini et al. 2005; McDowell et al. 2006; Zang et al. 2012; D'Amato et al. 2013).

In this study, we found some evidence that SI affected drought response, but the influence varied across species and between the two drought events. For northern red oak, there was strong evidence that SI positively influenced $\mathrm{BAI}_{\text {recovery }}$ and $\mathrm{BAI}_{\text {resistance }}$ during the first and second drought, respectively. Although a low-ranked model suggested that SI positively affected $\mathrm{BAI}_{\text {resilience }}$ during the first drought, the strength of evidence was relatively low. In contrast, we found strong support that SI negatively affected the BAI $\mathrm{I}_{\text {recovery }}$ of northern red oak during the second drought. Black oak was the only other species to display a relationship between SI and drought response. Although the strength of evidence was low, we did identify a negative effect of SI (in the context of the additive model) on $\mathrm{BAI}_{\text {resilience }}$ during the second drought. Positive relationships between $\mathrm{BAI}_{\text {recovery }}$ and $\mathrm{BAI}_{\text {resilience }}$ and SI during the first drought and $\mathrm{BAI}_{\text {resistance }}$ and SI during the second drought confirms that northern red oak growth during and after drought is reduced to a greater degree on poorly versus highly productive sites (Tainter et al. 1990). These positive relationships between drought indices and SI are likely related to the fact that SI is negatively correlated with soil moisture deficit (Klinka and Carter 1990; Kayahara et al. 1997; Chen et al. 2002). Consequently, on highly productive sites (i.e., high SI values), soil moisture availability, even during the two drought events, may not have been reduced to levels that would have limited individual tree growth. Changes in biomass allocation patterns, such as lower allocation to fine-root biomass as stands/trees age and site productivity increases (Keyes and Grier 1981; Vogt et al. 1987), may be, in part, responsible for the negative relationships observed between SI and drought indices for northern red and black oak during the second drought; an event that occurred 19-20 years after the first drought.

There is a growing body of literature that describes and quantifies the interacting effects of competition and climate, and drought, in particular, on individual tree growth (e.g., Kohler et al. 2010; Martínez-Vilalta et al. 2012; Magruder et al. 2013; Keyser and Brown 2014; Sánchez-Salguero 
et al. 2015). Thinning increases individual tree growing space and reduces competition for soil moisture (Martín-Benito et al. 2010). Additionally, soil moisture availability often increases postthinning due to reduced stand-level transpiration and increased canopy throughfall (Aussenac and Granier 1988; Bréda and Granier 1996; Bréda et al. 1996). Unlike previous studies quantifying the impact of density on drought response of coniferous (e.g., Mission et al. 2003; D’Amato et al. 2013) and deciduous broadleaved forest tree species (e.g., Merlin et al. 2015), we found a very limited effect of density on various drought indices. The decreased resistance of black oak at progressively greater RD observed during the first drought partially supports our hypothesis regarding density and tree growth during drought. The fact the that effect of RD was drought-specific has been observed in Norway spruce (Picea abies L. (Karst.)) plantations in Europe and led authors to suggest that the positive effects of reduced density via thinning on resistance to drought may be short-lived (Mission et al. 2003; Kohler et al. 2010; Sohn et al. 2013). The first and second drought occurred 10-11 years and 31-32 years postthinning, respectively. In the case of the second drought, recovery of biomass and reoccupation of growing space in plots of progressively lower densities may have ameliorated any increase in soil moisture, nutrient, and/or light availability that often follows thinning operations. Our results suggest that the effects of density may be confounded by the length of time between thinning interventions and individual drought events (Sohn et al. 2013). Contrary to our hypothesis, density had a positive effect on the $\mathrm{BAI}_{\text {recovery }}$ of northern red oak during the first drought event. Like Sohn et al. (2013), we found the positive relationship between density and recovery to be ambiguous. The lack of an effect of RD on the drought indices of the two species in the white oak group is consistent with the suggestion by LeBlanc and Terrell (2011) that the growth of species in the white oak group is less affected by stand dynamics and competition than of species in the red oak group.

The lack of a consistent effect of RD, SI, and/or DBH across species and drought events in this study may be the result of our sampling procedures. In this study, we limited sampling to those individuals in dominant and codominant canopy positions. In regard to stem size, these individuals often possessed the largest $\mathrm{DBH}$ values within their respective plots. Additionally, regardless of the competitive environment (i.e., density), these relatively large individuals in the upper canopy layers experience less competitive pressure for aboveground and belowground resources than do smaller individuals. The thinning prescription carried out in 1974/1975 was a low thinning, removing individuals in the suppressed and intermediate canopy positions until the target residual density was achieved. Therefore, growing space within the upper canopy layers remained, for the most part, unchanged by thinning. In oak forests, competition between dominant/codominant oak trees and smaller individuals in the lower canopy layers is minimal and does not affect the survival (Ward and Stephens 1994) or growth of canopy oaks (Kelty et al. 1987; Kittredge 1988). Previous research has demonstrated a differential response to drought of some eastern US oak species between the lower and upper canopy layers (Orwig and Abrams 1997). Sampling of suppressed and intermediate individuals within the context of this study would have been limited due to (1) the low thinning that removed individuals in the lower canopy layers and (2) the low abundance of oak in the lower canopy layers (i.e., sapling and pole-sized individuals) (Nowaki et al. 1990; McWilliams et al. 2002) in southern Appalachian hardwood stands. In addition, this study did not address the potential effects of stand composition (e.g., diversity measures) on tree growth response to drought. Recent evidence suggests that stand composition can modify tree response to drought through niche complementarity (e.g., differences in rooting depth) and various facilitative processes (Lebourgeois et al. 2013; Grossiord et al. 2014). For example, Pretzsch et al. (2013) documented that growth of European beech (Fagus sylvatica (L.)) during drought decreased less in mixed-species stands than in pure stands presumably due to the hydraulic lift of water associated with deeprooted co-occurring oak species. Because of our sampling procedures and the potential for stand composition (singularly or via interactions with $\mathrm{SI}, \mathrm{DBH}$, and/or $\mathrm{RD}$ ) to alter tree-level drought response, caution should be used when generalizing the results beyond the relatively limited scope of this study.

\section{Conclusion}

The direct and indirect effects of drought, including decreased tree- and stand-level productivity and increased tree mortality, have the potential to affect ecosystem structure, function, and composition (e.g., Dale et al. 2001; Zhao and Running 2010) making the development of adaptation strategies that promote the resistance or resilience of forest stands and landscapes to the negative effects of drought of ecological and economic importance (Vose and Klepzig 2013). For tree growth and productivity, an increase in frequency and severity of drought events will likely manifest in decreased tree- and stand-level growth and increased tree mortality (Allen et al. 2010).

In these even-aged mixed deciduous broadleaved forests, adaptation strategies for climate change are focused on increasing resistance or resilience to perturbations and stressors, including drought, as species composition is already dominated by relatively drought-tolerant oak species. Oak species vary in their relative tolerance and response to drought (Abrams 1990), which is consistent with the variability in resistance, recovery, and resilience indices we observed in this study. Species in the white oak group are generally longer lived, more tolerant of shade, slower growing, and more drought-tolerant than are species in the red oak group (Abrams 1990; Abrams 2003; 
Johnson and Abrams 2009). In general, stem size, density, and site productivity failed to consistently explain the growth response of four of the predominant oak species to drought in Appalachian hardwood stands. Studies have forecasted that future climate will result in an increase in the abundance and potential habitat for species in the white oak group in much of the eastern USA (Iverson and Prasad 1998; Iverson and Prasad 2002; McKenney-Easterling et al. 2000). The lack of sensitivity of the two white oak species - chestnut and white oak - to the range of density, stem size, and site productivity observed in this study as well as generally better resistance, recovery, and resilience indices suggests that management activities that focus on the regeneration, establishment, and/or retention of white oak versus red oak species, as opposed to a single silvicultural low thinning (to the levels of density observed in this study), may be one of the many possible strategies for sustaining the growth and productivity of oak species in Appalachian hardwood stands under a changing climate. To make more definitive conclusions regarding the ability of thinning to increase the overall drought resilience of these four prominent oak species, alternative thinning interventions (e.g., high thinning, free thinning, variable density thinning, etc.) that result in greater structural heterogeneity than did the single low thinning conducted in this study as well as the potential influence of species composition on drought response should be evaluated.

\begin{abstract}
Acknowledgments We thank the many scientists and technicians who worked on the original study throughout the years. We extend a special thanks to Charlie Possee who collected and prepared all the increment cores. Stan Zarnoch and two anonymous reviewers provided useful suggestions for the improvements of earlier versions of this manuscript. This paper was written and prepared, in part, by a US Government employee on official time, and therefore, it is in the public domain and not subject to copyright.
\end{abstract}

\section{Compliance with ethical standards}

Funding This study was funded by the Upland Hardwood Ecology and Management Work Unit (RWU-4157) of the USDA Forest Service, Southern Research Station.

\section{References}

Abrams MD (1990) Adaptations and responses to drought in Quercus species of North America. Tree Physiol 7:227-238. doi:10.1600 /036364415X688754

Abrams MD (2003) Where has all the white oak gone? Bioscience 53: 927-939. doi:10.1641/0006-3568(2003)053[0927:WHATWO]2.0. $\mathrm{CO} ; 2$

Adams HD, Guardiola-Claramonte M, Barron-Gafford GA, Villegas JC, Breshears DD, Zou CB, Troch PA, Huxman TE (2009) Temperature sensitivity of drought-induced tree mortality portends increased regional die-off under global-change-type drought. Proc Natl Acad Sci 106:7063-7066. doi:10.1073/pnas.0901438106
Allen CD, Macalady AK, Chenchouni H, Bachelet D, McDowell N, Vennetier M, Kitzberger T, Rigling A, Breshears DD, Hogg EH, Gonzalez P, Fensham R, Zhang Z, Castro J, Demidova N, Lim JH, Allard G, Running SW, Semerci A, Cobb N (2010) A global overview of drought and heat-induced tree mortality reveals emerging climate change risks for forests. For Ecol Manag 259:660-684. doi:10.1016/j.foreco.2009.09.001

Anderegg WRL, Kane JM, Anderegg LDL (2012) Consequences of widespread tree mortality triggered by drought and temperature stress. Nat Clim Chang 3:30-36. doi:10.1038/NCLIMATE1635

Anderegg WRL, Schwalm C, Biondi F, Camarero JJ, Koch G, Litvak M, Ogle K, Shaw JD, Shevliakova E, Williams AP, Wolf A, Ziaco E, Pacala S (2015) Pervasive drought legacies in forest ecosystems and their implications for carbon cycle models. Science 349:528-532. doi:10.1126/science.aab1833

Aussenac G, Granier A (1988) Effects of thinning on water stress and growth in Douglas-fir. Can J For Res 18:100-105

Beck DE (1983) Thinning increases forage production in southern Appalachian cove hardwoods. South J Appl For 7:53-57

Boisvenue C, Running SW (2006) Impacts of climate change on natural forest productivity - evidence sine the middle of the twentieth century. Glob Chang Biol 12:862-882. doi:10.1111 j.1365-2486.2006.01134.x

Bolte A, Rahmann T, Kurh M, Pogoda P, Murach D, Gadow K (2004) Relationships between tree dimension and coarse root biomass in mixed stands of European beech (Fagus sylvatica L.) and Norway spruce (Picea abies [L.] Karst. Plant Soil 264:1-11. doi:10.1023 /B:PLSO.0000047777.23344.a3

Bond-Lamberty B, Wang C, Gower ST (2002) Aboveground and belowground biomass and sapwood area allometric equations for six boreal tree species of northern Manitoba. Can J For Res 32:14411450. doi: $10.1139 / \mathrm{x} 02-063$

Bréda N, Badeau B (2008) Forest tree responses to extreme drought and some biotic events: towards a selection according to hazard tolerance. Geoscience 340:651-662. doi:10.1016/j.foreco.2015.06.008

Bréda N, Granier A (1996) Intra and interannual variations of transpiration, leaf area index and radial growth of sessile oak stand (Quercus petraea. Ann For Sci 52:23-42

Bréda N, Granier A, Aussenac G (1996) Effects of thinning on soil and tree water relations, transpiration and growth in an oak forest (Quercus petraea (Matt.) Liebl. Tree Physiol 15:295-306

Bréda N, Huc R, Granier A, Dreyer E (2006) Temperate forest trees and stands under severe drought: a review of ecophysiological responses, adaptation processes and long-term consequences. Ann For Sci 63:625-644. doi:10.1051/forest:2006042

Brzosetk ER, Dragoni D, Schmid HP, Rahman F, Sims D, Wayson CA, Johnson DJ, Phillips RP (2014) Chronic water stress reduced tree growth and the carbon sink of deciduous hardwood forests. Glob Chang Biol 20:2534-2532. doi:10.1111/gcb.12528

Burnham KP, Anderson DR (2002) Model selection and multimodel inference: a practical information-theoretic approach. Springer, New York, New York

Chen HYH, Krestov PV, Klinka K (2002) Trembling aspen site index in relation to environmental measures of site quality at two spatial scales. Can J For Res 32:112-119. doi:10.1139/X01-179

Chen G, Tian H, Zhang C, Liu M, Ren W, Zhu W, Chappelka AH, Prior SA, Lockaby GB (2012) Drought in the southern United States over the 20th century: variability and its impacts on terrestrial ecosystem productivity and carbon storage. Clim Chang 114:379-397. doi:10.1007/s10584-0120410-Z

Clinton BD, Boring LR, Swank WT (1993) Canopy gap characteristics and drought influences in oak forests of the Coweeta Basin. Ecology 74:1551-1558. doi:10.2307/1940082 
Copenheaver CA, Crawford CJ, Fearer TM (2011) Age-specific responses to climate identified in the growth of Quercus alba. Trees 25:647-653. doi:10.1007/s00468-011-0541-2

D'Amato AW, Bradford JB, Fraver S, Palik BJ (2013) Effects of thinning on drought vulnerability and climate response in north temperate forest ecosystems. Ecol Appl 23:1735-1742. doi:10.1890/130677.1

Dale VH, Joyce LA, McNulty S, Neilson RP, Ayres MP, Flannigan MD, Hanson PJ, Irland LC, Lugo AE, Peterson CJ, Simberloff S, Swansoon FJ, Stocks BJ, Wotton BM (2001) Climate change and forest disturbances. Bioscience 51:723-734. doi:10.1641/00063568(2001)051[0723:CCAFD]2.0.CO;2

Desprez-Loustau ML, Marcais B, Nageleisen LM, Priou D, Vannini A (2006) Interactive effects of drought and pathogens in forest trees. Ann For Sci 63:597-612. doi:10.1051 /forest:2006040

Doolittle WT (1958) Site index comparisons for several forest species in the southern Appalachians. Soil Sci Soc Am Pro 22:455-458

Elliott KJ, Swank WT (1994) Impacts of drought on tree mortality and growth in a mixed hardwood forest. J Veg Sci 5:229-235. doi: $10.2307 / 3236155$

Elliott KJ, Miniat CF, Pederson N, Laseter SH (2015) Forest tree response to hydroclimate variability in the southern Appalachians. Glob Chang Biol 21:4627-2641. doi:10.1111/gcb.13045

Fei SL, Kong NN, Steiner KC, Moser WK, Steiner EB (2011) Change in oak abundance in the eastern United States from 1980 to 2008. For Ecol Manag 262:1370-1377. doi:10.1016/j.foreco.2011.06.030

Fekedulegn D, RR H Jr, Colbert JJ (2003) Influence of topographic aspect, precipitation and drought on radial growth of four major tree species in an Appalachian watershed. For Ecol Manag 117:409 425. doi:10.1016/S0378-1127(02)00446-2

Gea-Izquierdo G, Martin-Benito D, Cherubini P, Canellas I (2009) Climate-growth variability in Quercus ilex L. west Iberian open woodlands of different stand density. Ann For Sci 66:802-813. doi:10.1051/Forest/2009080

Gómez-Aparicio L, García-Valdéz R, Ruíz-Benito P, Azvala MA (2011) Disentangling the relative importance of climate, size and competition on tree growth in Iberian forests: implications for forest management under global change. Glob Chang Biol 17:2400-2414. doi:10.1111/j.1365-2486.2011.02421.x

Grossiord C, Granier A, Ratcliffe S, Bouriaud O, Bruelheide H, Chećko E, Forrester DI, Dawud SM, Finér L, Pollastrini M, SchererLorenzen M, Valladares F, Bonal D, Gessler A (2014) Tree diversity does not always improve resistance of forest ecosystems to drought. P Natl. Acad Sci 111:14812-14815. doi:10.1073/pnas.1411970111

Haavik LJ, Billings SA, Guldin JM, Stephen FM (2015) Emergent insects, pathogens and drought shape changing patterns in oak decline in North America. For Ecol Manag 354:190-205. doi:10.1016/j. foreco.2015.06.019

Hanewinkel M, Cullmann DA, Schelhaas MJ, Nabuurs GJ, Zimmermann NE (2013) Climate change may cause severe loss in the economic value of European forest land. Nature. Clim Chang 3:203-207. doi:10.1038/nclimate1687

Harrison WC, Burk TE, Beck DE (1986) Individual tree basal area increment and total height equations for southern Appalachian mixed hardwoods after thinning. South J Appl For 10:99-104

Holmes RL (1983) Computer-assisted quality control in tree-ring dating and measurement. Tree-Ring Bull 44:69-75

Iverson LR, Prasad AM (1998) Predicting abundance of 80 tree species following climate change in the eastern United States. Ecol Monogr 68:465-485. doi:10.1890/0012-9615(1998)068[0465:PAOTSF]2.0. $\mathrm{CO} ; 2$

Iverson LR, Prasad AM (2002) Potential redistribution of tree species habitat under five climate change scenarios in the eastern US. For Ecol Manag 155:205-222. doi:10.1016/S0378-1127(01)00559-X
Jenkins MA, Pallardy SG (1995) The influence of drought on red oak group species growth and mortality in the Missouri Ozarks. Can J For Res 25:1119-1127. doi:10.1139/x95-124

Johnson SE, Abrams MD (2009) Age class, longevity and growth rate relationships: protracted growth increases in old trees in the eastern United States. Tree Physiol 29:1317-1328. doi:10.1093 /treephys/tpp068

Kayahara GJ, Klinka K, Schroff AC (1997) The relationship of site index to synoptic estimates of soil moisture and nutrients for wester redcedar (Thuja plicata) in southern British Columbia. Northwest Sci 71:167-173

Kelty MJ, Could EM Jr, Twery MJ (1987) Effects of understory removal in hardwood stands. North J Appl For 4:162-164

Keyes MR, Grier CC (1981) Above-ground and below-ground net production in 40-year-old Douglas-fir stands on low and high productivity sites. Can J For Res 11:599-605

Keyser CE (2008) (revised November 2, 2015). Southern (SN) variant overview-forest vegetation simulator. USDA For Serv, Forest Management Service Center, Internal Rep. Fort Collins, Colorado Center. http://www.fs.fed.us/fmsc/ftp/fvs/docs/overviews/FVSsn Overview.pdf. Accessed 3 February 2016

Keyser TL, Brown PM (2014) Climate-growth relationships for yellowpoplar across structural and site quality gradients in the southern Appalachian Mountains. For Ecol Manag 229:158-165. doi:10.1016/j.foreco.2014.06.015

Keyser TL, Malone J, Cotton C, Lewis J (2014) Outlook for Appalachian-Cumberland forests: a subregional report from the southern forest futures project. USDA For Serv Gen Tech Rep GTR-188. Southern Research Station, Asheville, North Carolina

Kittredge DB Jr (1988) The influence of species composition on the growth of individual red oaks in mixed stands in southern New England. Can J For Res 18:1550-1555

Klinka K, Carter RE (1990) Relationships between site index and synoptic environmental factors in immature coastal Douglas-fir stands. For Sci 36:815-830

Klos RJ, Wang GG, Bauerle WL, Rieck JR (2009) Drought impact on forest growth and mortality in the southeast USA: an analysis using Forest Health and Monitoring data. Ecol Appl 19:699-708. doi:10.1890/08-0330.1

Kohler M, Sohn J, Nagele G, Bauhus J (2010) Can drought tolerance of Norway spruce (Picea abies (L.) karst.) be increased through thinning? Eur J Forest Res 129:1109-1118. doi:10.1007/s10342-0100397-9

LeBlanc DC (1998) Interactive effects of acidic deposition, drought, and insect attack on oak populations in the midwestern United States. Can J For Res 28:1184-1197. doi:10.1139/cjfr-28-8-1184

LeBlanc DC, Foster JR (1992) Predicting effects of global warming on growth and mortality of upland oak species in the Midwestern United-States - a physiologically based dendroecological approach. Can J For Res 22:1739-1752

LeBlanc DC, Terrell MA (2011) Comparison of growth-climate relationships between northern red oak and white oak across eastern North America. Can J For Res 41:1936-1947. doi:10.1139/X11-118

Lebourgeois F, Gomez N, Pinto P, Mérian P (2013) Mixed stands reduce Abies alba tree-ring sensitivity to summer drought in the Vosges mountains, western Europe. For Ecol Manag 303:61-71. doi:10.1016/j.foreco.2013.04.003

Lebourgeois F, Eberlé P, Mérian P, Seynave I (2014) Social statusmediated tree-ring responses to climate of Abies alba and Fagus sylvatica shift in importance with increasing stand basal area. For Ecol Manag 328:209-218. doi:10.1016/jforeco.2014.05.038

Linares JC, Camarero JJ, Carreira JA (2010) Competition modulates the adaptation capacity of forests to climatic stress: insights from recent growth decline and death in relic stands of the Mediterranean fir Abies pinsapo. J of Ecol 98:592603. doi:10.1007/s11104-012-1397-y 
Lloret F, Keeling EG, Sala A (2011) Components of tree resilience: effects of successive low-growth episodes in old ponderosa pine forests. Oikos 120:1909-1920. doi:10.1111 j. 1600-0706.2011.19372.x

Magruder M, Chhin S, Palik B, Bradford JB (2013) Thinning increases climatic resilience of red pine. Can J For Res 43:878-889. doi:10.1139/cjfr-2013-0088

Martin JG, Kloeppel BD, Schaefer TL, Kimbler DL, McNulty SG (1998) Aboveground biomass and nitrogen allocation of ten deciduous southern Appalachian tree species. Can J For Res 28:1648-1659. doi:10.1139/x98-146

Martin-Benito D, del Rio M, Heinrich I, Helle G, Canellas I (2010) Response of climate-growth relationships and water use efficiency to thinning in a Pinus nigra afforestation. For Ecol Manag 259:967975. doi:10.1016/j.foreco.2009.12.001

Martínez-Vilalta J, López BC, Loepfe L, Lloret F (2012) Standand tree-level determinants of the drought response of Scots pine radial growth. Oecologia 168:877-888. doi:10.1007 /s00442-011-2132-8

McDowell N, Adams H, Bailey J, Hess M, Kolb T (2006) Homeostatic maintenance of ponderosa pine gas exchange in response to stand density changes. Ecol Appl 16:11641182. doi:10.1890/1051-0761(2006)016[1164:HMOPPG]2.0. $\mathrm{CO} ; 2$

McKenney-Easterling M, DeWalle DR, Iverson LR, Prasad AM, Buda AR (2000) The potential impacts of climate change and variability on forests and forestry in the mid-Atlantic region. Clim Res 14:195206. doi: $10.3354 / \mathrm{Cr} 014195$

McNab WH (2011) Subregional variation in upland hardwood forest composition and disturbance regimes of the central hardwood region. In: Greenberg CH, Collins BS, Thompson FRIII (eds) Sustaining young forest communities: ecology and management of early successional habitats in the central hardwood region, USA. Springer, New York, pp. 11-26

McNulty S, Moore Meyers J, Caldwell P, Sun G (2013) Climate change summary. In: Wear DN, Gries JG (eds) The southern forest futures project: technical report. USDA For Serv Gen Tech Rep SRS-178, Southern Research Station, Asheville, North Carolina, pp. 27-43

McShae WJ, Healy WM, Devers P, Fearer T, Koch KH, Stauffer D, Waldon J (2007) Forestry matters: decline of oaks will impact wildlife in hardwood forests. J Wildl Manag 71: 1717-1728. doi:10.2193/2006-169

McWilliams WH, O’Brien RA, Reese GC, Waddell KL (2002) Distribution and abundance of oaks in North America. In: McShea WJ, Healy WM (eds) Oak forest ecosystems: ecology and management for wildlife. John Hopkins University Press, Baltimore, Maryland, pp. 13-33

Mencuccini M, Martinez-Vilalta J, Vanderklein D, Hamid HA, Korakaki E, Lee S, Michiels B (2005) Size-mediate ageing reduces vigour in trees. Ecol Lett 8:1183-1190. doi:10.1111 j.1461-0248.2005.00819.x

Mérian P, Lebourgeois F (2011) Size-mediate climate-growth relationships in temperate forest: a multi-species analysis. For Ecol Manag 261:1382-1391. doi:10.1016/j.foreco.2011.01.019

Merlin M, Perot T, Perret S, Korboulewsky N, Vallet P (2015) Effects of stand composition and tree size on resistance and resilience to drought in sessile oak and Scots pine. For Ecol Manag 339:22-33. doi:10.1016/j.foreco.2014.11.032

Mission L, Vincke C, Devillez F (2003) Frequency responses of radial growth series after different thinning intensities in Norway spruce (Picea abies (L.) karst.) stands. For Ecol Manag 177:51-63. doi:10.1016/S0378-1127(02)00324-9

Nowaki GJ, Abrams MD, Lorimer CG (1990) Composition, structure, and historical development of northern red oak stands along an edaphic gradient in north-central Wisconsin. For Sci 36:276-292
Olson DF, Jr (1959) Site index curves for upland oak in the southeast. USDA for Serv res pap SE-123. Southeastern Forest Experiment Station, Asheville, North Carolina

Orwig DA, Abrams MD (1997) Variation in radial growth responses to drought among species, site, and canopy strata. Trees 11:44-484. doi: $10.1007 / \mathrm{s} 004680050110$

Pan C, Tajchman SJ, Kochenderfer JN (1997) Dendroclimatological analysis of major forest species of the central Appalachians. For Ecol Manag 98:77-87. doi:10.1016/S0378-1127(97)00087-X

Pedersen BS (1998) The role of stress in the mortality of midwestern oaks as indicated by growth prior to death. Ecology 79:79-93. doi: $10.2307 / 176866$

Piutti E, Cescatti A (1997) A quantitative analysis of the interactions between climatic response and intraspecific competition in European beech. Can J For Res 27:277-284. doi:10.1139/x96-176

Pretzsch H, Schütze G, Uhl E (2013) Resistance of European tree species to drought stress in mixed versus pure forests: evidence of stress release by inter-specific facilitation. Plant Biol 15:483-495. doi:10.1111/j.1438-8677.2012.00670.x

Reineke LH (1933) Perfecting a stand-density index for even-aged forests. J Agric Res 4:627-638

Roach BA (1977) A stocking guide for Allegheny hardwoods and its use in controlling intermediate cuttings. USDA for serv res pap NE-373. Northeastern Forest Experiment Station, Upper Darby, Pennsylvania

Sánchez-Salguero R, Linares JC, Camarero JJ, Madrigal-González J, Hevia A, Sánchez-Miranda A, Ballesteros-Cánovas JA, AlfaroSánchez R, García-Cervigón AI, Bigler C, Rigling A (2015) Disentangling the effects of competition and climate on individual tree growth: a retrospective and dynamic approach in Scotts pine. For Ecol Manag 358:12-25. doi:10.1016/j.foreco.2015.08.034

SAS Institute (2011) SAS Version 9.3. SAS Institute Inc., Cary, NC

Sohn JA, Gebhardt T, Ammer C, Bauhus J, Häberle KH, Matyssek R, Grams TEE (2013) Mitigation of drought by thinning: short-term and long-term effects on growth and physiological performance of Norway spruce (Picea abies. For Ecol Manag 308:188-197. doi:10.1016/j.foreco.2013.07.048

Sork VL, Bramble J, Sexton O (1993) Ecology of mast-fruiting in tree species of north American deciduous oaks. Ecology 74:528-541. doi: $10.2307 / 1939313$

Speer JH, Grissino-Mayer HD, Orvis KH, Greenberg CH (2009) Climate response of five oak species in the eastern deciduous forest of the southern Appalachian Mountains, USA. Can J For Res 39:507-518. doi:10.1139/X08-194

Stout SL, Nyland RD (1986) Role of species composition in relative density measurement in Allegheny hardwoods. Can J For Res 16: 574-579. doi:10.1139/x86-099

Tainter FH, Retzlaff WA, Oak SW, Starkey DA (1990) Decline in radial growth in red oaks is associated with short-term changes in climate. Eur J For Pathol 20:95-105

Tardiff J, Camarero JJ, Ribas M, Gutiérrez E (2003) Spatiotemporal variability in tree growth in the central Pyrenees: climatic and site influences. Ecol Monogr 73:241-257. doi:10.1890/0012-9615 (2003)073[0241:SVITGI]2.0.CO;2

Vayreda J, Martinez-Vilata J, Gracia M, Retana J (2012) Recent climate changes interact with stand structure and management to determine changes in tree carbon stocks in Spanish forests. Glob Chang Biol 18:1028-1041. doi:10.1111/f.1365-2486.2011.02606.x

Vogt KA, Vogt DJ, Moore EE, Fatuga BA, Redlin MR, Edmonds RL (1987) Conifer and angiosperm fine-root biomass in relation to stand age and site productivity in Douglas-fir forests. J Ecol 75:857-870

Vose JM, Klepzig K (2013) Climate change mitigation and management options: a guide for natural resource managers in southern forest ecosystems. CRC Press, Baca Raton, Florida. doi:10.1201/b15613-9 
Ward JS, Stephens GR (1994) Crown class transition rates of maturing northern red oak (Quercus rubra L. For Sci 40:221-237

White PB, Van de Gevel SL, Grissino-Mayer HD, LaForest LB, Deweese GG (2011) Climatic response of oak species across and environmental gradient in the southern Appalachian Mountains, USA. TreeRing Res 67:27-37. doi:10.3959/2009-1.1
Zang C, Pretzsch H, Rothe A (2012) Size-dependent responses to summer drought in scots pine, Norway spruce and common oak. Trees 26:557-569. doi:10.1007/s00468-011-0617-z

Zhao M, Running SW (2010) Drought-induced reduction in global terrestrial net primary productivity from 2000 through 2009. Science 329:940-943. doi:10.1126/science.1192666 